\title{
Factors Affecting the Demographic Compositional Change of Transoxiana in the Early Islamic Centuries
}

\author{
Mohsen Rahmati ${ }^{1}$ \\ ${ }^{1}$ Department of History, Lorestan University, Iran \\ Correspondence: Mohsen Rahmati, Associate Professor, Department of History, Lorestan University, Khoramabad, Iran.
}

Received: April 8, 2018 Accepted: April 22, 2018 Online Published: May 2, 2018

doi:10.5539/res.v10n2p141 URL: https://doi.org/10.5539/res.v10n2p141

\begin{abstract}
Despite the frequent attacks of Nomad tribes of the northern plains, the demographic composition of Transoxiana had remained Iranian in ancient era; nevertheless, after Muslim Arabs prevalence until the Mongol invasion, the demographic composition of this area completely changed under the influence of different factors. In addition to identifying the demographic composition of Transoxiana in the first Islamic centuries, this study is intended to introduce the factors affecting the transformation of the demographic change of this area. This study shows that in the Early Islamic centuries, the political structure and ethnic-racial of Transoxiana changed under the influence of different factors as Arab Conquests, Geographical Location of Transoxiana, Refuge of the opponents of caliphs, Commerce, Ghaza, The Religious Importance and Prosperity of Scientific Schools, Political Centralization in the Region by the Samanids, conversion of Turk Nomads to Islam, Migration of Turk Tribes to the region and Migration of that Inhabitants.
\end{abstract}

Keywords: Ethnic texture, Demographic composition, Transoxiana, Arabs, Turks, Samanids

\section{Introduction}

In each of the human societies, like many other social characteristics, demographic composition is changed and transformed over time. As some areas where is the birthplace and housing of a specified ethnic, becomes the home of another ethnic and group after a period. Thus, studying these transformations of demographic composition of different areas over centuries is one of the most important and considerable issues in the social history. Among Iranian areas that have experienced transformation in their ethnic texture and demographic composition over time, Transoxiana has a special position.

During the ancient period until the first Islamic centuries, this area now the home of Turk and Mongol tribes (including Uzbeks, Kyrgyz, Kazakh, Turkmen, Tatar, Uyghur, Qaraqalpaq, etc.) and is called by their names Uzbekistan, Kyrgyzstan, or Turkmenistan has been the center of the establishment of Iranian tribes and groups and considered as the largest and the most eastern Iranian state. The great role that this area played in the revival of scientific-literature life of Iran in the $9^{\text {th }}$ and $10^{\text {th }}$ centuries, the genesis and development of Persian literature, as well as the emergence and expansion of Iranian-Islamic culture and civilization makes us to study and review its deep transformations; especially since there was a close relationship among the changes of that region with the other places of Iran. As the transformation in political and social structure of Transoxiana was the introduction and beginning of this series of developments in all western parts of Iran. With locating in the major trade routes of Asia, in addition to benefitting from the possibility of commercial and industry development, this area was exposed to the passage of groups and individuals of different societies; consequently, there was a continuous change in its demographic texture. The process of this transformation of ethnic groups in Transoxiana became more intense over the first Islamic centuries; so that in the early Islamic centuries and under the influence of various factors such as distance of the area from the caliphate center, the commercial importance of the region, growth and prosperity of Ghaza operations, prosperity of religious sciences schools in the area, and finally, Islamism of Turks living in the Northern Plains on the Yaxartes, the context of transformation in the fully Iranian ethnic texture and demographic composition of this region was provided.

\subsection{Literature Review}

So far, several and various studies have been conducted on the history and society of Transoxiana in the early Islamic centuries; and the author has used most of these papers in writing this text. Most of these studies have been focused on explaining the political history or the status of the social classes of the region and the ethnic texture change has been less paid attention to. Only Spuler has briefly focused on the ethnic texture change all over Iranshahr (Iran Land) from Euphrates to Yaxartes and described this change without explaining the reasons of the issue. ${ }^{i}$ Given the wide scope of his 
discussion, it is natural that his data on Transoxiana is very few. Therefore, the aim of the current study is to clearly answer the question that: "why and how have the ethnic texture and demographic composition of Transoxiana changes in the early Islamic centuries?"

\section{The Demographic Composition of Transoxiana on the Verge of Islamic Conquests}

Our first knowledge of Transoxiana dates back to Achaemenid era when the eastern borders of that government stretched to Yaxartes. However there is almost no information about the domestic events of the region in Achaemenid era, but the geographical names of this region mentioned in the inscriptions of the Achaemenid kings confirms its political affiliation with Iran. ${ }^{\text {ii }}$ This political integration and loyalty of the residents of Transoxiana continued until the last days of Achaemenid Empire (Toynbee, 685-686) all political-administrative arrangements of Achaemenid era in the region continued in the era of Alexander and Seleucids. ${ }^{\text {iii }}$ The weakness of Seleucid Empire in this region provided the field for the movements of the northern emigrant tribes in the $9^{\text {th }}$ century. A group of Iranian emigrant tribes called Takhars exorcised the Scythians around Yaxartes to Transoxiana and Khorasan and then established Kushan Empire in the Eastern Khorasan and Transoxiana. ${ }^{\text {iv }}$ The general belief is that also these tribes had and Aryan root. According to the clear historical evidence, by the predominance of the Sassanid kings on Kushan Empire, Transoxiana was put under the command of the Sassanid Kings; ${ }^{\mathrm{v}}$ and with all its rise and falls, this dominance of Sassanid Empire on Transoxiana remained at least until the end of the fifth century. ${ }^{\mathrm{vi}}$ Nevertheless, at this time, with the massive invasion of the last group of Aryan emigrants called Heptalians, and half a century after them, the first non-Aryan emigrants called Turks overwhelmed the resistance of Sassanid Kings and local independent peasantries and this region was put under the domination of invaders. The kingdom of Heptalians and Turks was so transient and unstable that left no lasting effect and did not have any serious critique to the [status of] commerce and the increasing advancement trend of Transoxiana. Like Kushans, Heptalian gradually settled in the Iranian population. In our resources, there is no sign or indication of the wide migration of Turks to the overwhelmed territories. In general, the intervention of Turks in the administrative system of the princes under their command in that land was first limited to the appointment of sheriffs and gathering of tributes. ${ }^{\text {vii }}$

Thus, when capturing the Transoxiana in the early $8^{\text {th }}$ century, Arabs faced small, independent and numerous political units ${ }^{\text {viii }}$ that in addition to internal competitions, were in challenge against the desert masters of the region (i.e., the Turks' remnants) that appeared well to Arabs and this was one of the main factors of facilitation of Arab conquests in that area. ${ }^{\text {ix }}$ At the beginning, the emigrant desert tribes created a complete turmoil; nevertheless, it seems that they were rapidly attracted by the indigenous elements and settled in the Iranian demographic texture of the region. During all centuries that the attacks of desert tribes continued, the base of the demographic texture of Transoxiana remained Iranian with preserving its language and customs. Therefore, until the Arab conquests among the inhabitants of Transoxiana and Khorasan, there were significant interactions and in spite of the political differences, there were common elements for a cultural and ethnic unity among them.

\section{Factors Affecting the Transformation of Demographic Composition of Transoxiana}

This evolution in the ethnic texture and demographic composition was generated under the influence of specific factors and conditions whose affection will be addressed and expressed in the following:

\subsection{Arab Conquests}

after the death of Yazdgird in the year 651, Khorasan was dominated by Muslim Arabs; however, the consolidation of this domination was achieved only after the migration and establishment of a group of Arabs by Ziad Ibn Abih (664-672) in that area. ${ }^{x}$ By consolidation of the domination of Arabs on Khorasan, the first military groups of Arabs under the command of 'Obaidollah Ibn Ziad passed Oxus in the year 672 and started attacking Transoxiana. ${ }^{\text {xi }}$ Given the existence of Oxus as well as the unfavorable political and social conditions in the Islamic territory in the second half of the first Islamic century, the establishment of Arabs in Transoxiana and final conquest of it were not possible. Hence, up to a half century later, these attacks continued in seasonal form and with a predatory approach. That is, in the war seasons of the year, they attacked there and after achieving the spoils, they returned to Khorasan in autumn. ${ }^{\text {xi }}$ Thus, the final conquest and permanent attachment of this area to the Islamic territory was only dependent to the permanent residence of a group of Arab tribes in Transoxiana; hence, Qutaiba Ibn Muslim Baheli (704-714) made it possible for a significant population of Arabic tribes in Transoxiana area to provide the preliminaries of this affair. He also put a group of Arab fighters as Garisson in the cities of this area. ${ }^{\text {xiii }}$ So that, after the certain conquest of Transoxiana, the entrance to that area became possible for the Arabs.

Therefore, Arabs' conquests affected the demographic composition of Transoxiana in two ways; in one hand, by the extensive establishment of Arabs in the area, the base of an Arabic demographic core was founded there; Transoxiana, especially Bukhara was from the areas that were paid attention to by Arab when their conquests and many Arab tribes migrated to these areas and resided around them. ${ }^{\text {xiv }}$ As according to Ya'qubi, in the middle of the $9^{\text {th }}$ century, Ushrawsna was the only area in Transoxiana where Arabs had not resided, unless, many Arabs had resided in all parts of 


\section{Transoxiana. ${ }^{\mathrm{xv}}$}

On the other hand, with the establishment of Arabs in the area, a large number of local noblesse and powerful people that were dissatisfied with the domination or even proximity to the Arabs preferred to leave their country instead of residence in there and migrated to the eastern parts of the country collectively. ${ }^{\mathrm{xvi}}$ So that, a large part of the Iranian noblesse (Sughdi) of the area migrated to Semirchie region and resided there. Some other noblesse went from the cities to the rural areas around the cities and left the cities for the Arabs. ${ }^{\text {xii }}$ Therefore, a significant change occurred in the demographic composition of the region after the Islamic conquests in the area.

\subsection{Geographical Location of Transoxiana}

Transoxiana was indeed the most eastern province of the Islamic territory that was important due to its lack of access to the caliphate as well as two other reasons; one was its proximity to the wide deserts of Turkestan from the north and east and the other was its location in the communication path between west Asia and India and China. Therefore, during the early Islamic centuries, the geographical location of Transoxiana affected the transformation of the demographic composition of the region in several ways that are investigated in the following, respectively:

\subsubsection{Refuge of the Opponents of Caliphs}

The proximity of Transoxiana with non-Muslim tribes, as well as lack of access to the caliphate provided a favorable place for the refuge of the opponents of the caliph. The most important opponents of the Caliph were Shiites and Kharijites whose focus was in Kufa and its adjoining areas, but they went to the eastern regions due to pursuing and bother of the caliphate system. In the meantime, although the Kharijites generally went to Sistan and the borders of India, some of them went to Transoxiana and settled around Oxus in the Termidh area. ${ }^{\text {xiii }}$ The Shiites turned more extensively to Transoxiana and immigrated to the eastern regions of the Transoxiana around Ilaq, Fergana and Chach. ${ }^{\text {xix }}$ In this process, Sadat Alavi was the most important ethnic group that migrated to Transoxiana. Those who regarded the caliphate to be the true right of their ancestors, Ali Ibn Abi Talib (AS) and considered the caliphs of the Umayyad and Abbasid as usurpers of this right, during the early Islamic centuries were under different pressures, persecution and torments from the caliphs of Umayyad and Abbasid. ${ }^{\mathrm{xx}}$

Even some caliphs had considered some spies for themselves in order to see the apparent and hidden activities of Sadat through them. ${ }^{\text {xi }}$ "Alid Sadat migrated to far areas for their safety from this persecution. ${ }^{\text {xii }}$ Due to its specific geographical location, Transoxiana was paid attention to by 'Alid Sadat from the beginning of the $8^{\text {th }}$ century. Delicate behavior of the people and rulers of that area (especially, Samanids) to Sadats also added their reasons and consequently, that area and its proximate lands became as one of the centers of Sadats. ${ }^{\text {xiii }}$ This extensive dispersion of 'Alid Sadat in the area can be deduced from their active presence in the political-military events of Transoxiana in eth fifth and sixth centuries as well as the detailed list of Alavi elders and paterfamilias in the cities of this region provided by Abu al-Hasan Baihaqi. This area was also a place for refuge of the other political opponents of Abbasid caliphate system, even for the members of (their own) family who claimed for the caliphate. ${ }^{\text {xiv }}$ So that, in the shadow of such position, a large number of Sadats and other Arabs came to Transoxiana and permanently resided there.

\subsubsection{Commerce}

Commerce has been always one of the main factors of demographic displacement. In the early Islamic centuries, Transoxiana region has been also considered as the only large commercial center among Khorasan, India, China, Turkestan, Qipchaq Plain, and through that to the Eastern Europe and the coasts of Baltic Sea. Due to the suitable communicative location, many residents of that area were engaged in commerce and distributed around for business. ${ }^{\mathrm{xx}}$ Moreover, many merchants travelled to this region from different areas. Many of these merchants either resided in cities of Transoxiana or established their agents in these cities for doing their commercial works; as during the time of Chingiz Khan's Attack to Bukhara, when they listed the rich people of Bukhara, 280 persons were selected of which 90 persons were merchants. ${ }^{\text {xxi }}$ In addition, just in the small city of Shalji around Taraz, in the east of Yaxartes, there were ten thousands merchants of Ispahan (apart from the merchants of the other cities). ${ }^{x v i i}$ As it is clear, this condition has intensively connected Transoxiana to Khorasan, Turkestan, and Qipchaq Plain and had numerous economic advantages for its inhabitants.

In addition, as we know, slave has been one of the greatest exchanged goods in these ages. The slave trade boom cause that many individuals of Turk tribes be sold as slaves (including bondman and bondwoman) in the slavery markets of the area and sent to the other parts of the world. ${ }^{\text {xxiii }}$ In the fourth century, the preparations of absorption and maintenance of these slaves were made in Transoxiana; i.e. while transferring and selling a large number of Turk slaves to the west areas of Islamic territory, Samanid court absorbed many of these slaves and gave them administrative and military works. The presence of these slaves gradually accounted for a significant percentage of the demographic composition of this area. 


\subsubsection{Ghaza}

The issuance of Islam and Jihad with non-Muslims has been always considered as a godly act by Muslims. Attachment of Transoxiana to the Islamic territory put the Muslim Arabs in eth proximity of non-Muslim tribes living in the northern and eastern Yaxartes plains. Since the common border of Muslims and non-Muslims was in Transoxiana and the lands around Yaxartes, fight with these non-Muslims had gradually influences on the area and Transoxiana has become a border area (Thaghr) and the place of gathering of Ghazi Muslims from the other Islamic territory areas. The necessity of fighting with the attacks of these desert tribes required the permanent presence of these Ghazians in the borders.

Thus, the many welfare facilities like Ribats, placing drinking water in the cities, free night-time catering to these Ghazis, and donating places for administrating these welfare centers were considered and consequently, many other Muslims of the other areas went to Transoxiana as Ghazi and got engaged with fighting with the desert tribes. ${ }^{\text {xxix }}$ As a result, in this period, many Ghazian and Mutawa'a (idol breakers) gathered there from different areas of the World of Islam and engaged in Jihad with the non-Muslim tribes of the northern deserts. ${ }^{\mathrm{xx}}$ Therefore, in one hand, Ghaza (Fighting with non-Muslims) brought many Ghazians from the other areas of the Islamic territory to Transoxiana and changed the demographic texture of the area; and on the other hand, as a result of these fights, many Turk slaves were entered Transoxiana. As mentioned, the entrance of these Turk slaves also affected the demographic texture of the area.

\subsection{The Religious Importance and Prosperity of Scientific Schools}

Another one of the attractions of the area contributing the demographic composition change of the region was the prosperity and plurality of religious sciences schools. All of the people of the region were Sunni and congregational and were generally the followers of Hanafi and Shafei parties. Shafeis presented around Chach and some villages of Bukhara, and most of inhabitants of the region were Hanafis. ${ }^{\mathrm{xxxi}}$ From the very beginning of the second century, a significant number of scientists and scholars of the region travelled to Hijaz and Iraq and trained before Hadith Imams and followers and consequently, many of these scientists became the religious leaders of Hanafis of the World of Islam. ${ }^{\text {xxxii }}$ Through the compilation of great Hadith Books such as "Șihāḥ al-Setta", these leaders obtained the spirituality of all Sunni people. In addition to consolidating the authority of the religion of their followers, the presence of great Sunni leaders in Khorasan and Transoxiana helped the prosperity of the religious sciences schools in the region; so that many science fans from different parts of the World of Islam went to this area to educate religious sciences and they generally resided there temporarily or permanently. ${ }^{\text {xxiii }}$ Thus, science educating was also another factor of changing the demographic composition of the region.

\subsection{Political Centralization in the Region}

In ancient era, the administrative-political structure of Transoxiana was influenced by the ancient Aryan traditions and the geographical location of the area had a poly-rulers structure. This means that the Iranian of Transoxiana traditionally were in under Aryan dominance of their indigenous bosses (called Zantopats) or local kings. ${ }^{\text {xxiv }}$ In one hand, regarding the geopolitical position of the region and its proximity to the desert tribes, and on the other hand, due to the geographical dispersion of its units, Achaemenid Empire that had created a central political power around the capital, with political tolerance and in addition applying its high comments, accepted the existing local political order or the same poly-rulers system and only by foundation of Satrapi of Bactria and appointing one of the members of royal family to its government, Achaemenid Empire put the responsibility of ruling there, full monitoring of tax collection, preparation of the troops, and coordination in the general policies of the empire in the eastern region on his shoulder. ${ }^{\mathrm{xxv}}$ In addition to monitoring the southern Oxus, this Satrap supervised the Basin of Marghab River, Transoxiana, and United kingdoms of the Empire. ${ }^{\text {xxxvi }}$ So that, a kind of administrative-political structure has been created that was the desired and interested method of the future rulers of that region; and more than fifteen centuries, the next powers including Maqdounian, Parthian, Kushanian, Sassanids, Heptalian, Turks, and even Muslim Arabs continued this political administrative structure. This means that by applying their high comments and collecting taxes, they maintain the internal independence of these indigenous kings that were ruling the different parts of Transoxiana as Dehqan.

After overcoming Khorasan, with the idea of imitation of the Sasanid Kings and changing their rule into Kingdom, Samanid Emirs that were from the same Dehqans and obtained their power from the same political structure changed the political structure through creating political centralization, got the power of the Dehqans, and started a long-lasting competition with them. As a result of this process, the Samanid Government dismissed many of these local Dehqans and seized their estates. ${ }^{x x x v i i}$ By comparing the number of powerful Dehqans in Bukhara oasis when the Arab conquests with the time of Emir Ismail that no powerful Dehqan remained, we can realize the intensity and depth of this political centralization. As in the distance between Yaxartes River and Oxus River that had been sometime full of independent small emirates, now there was only one rule and that was the rule of Sasanid Emir. Even Samanid Emirs dismissed some of their brothers and family members ruling around Yaxartes and attached their territory to their own direct territory.

This political centralization that threatened the interests and political position of Dehqans made them to oppose the 
Samanid Emirs that appeared over several stages and in the form of several revolts against Sassanid Emirs including provocation of the slaves to murder Amir Ahmad, participation in the revolt of Hussein Ibn Ali Marwrudi, revolt of Ahmad Ibn Sahl Marwrudhi. ${ }^{x x x v i i i}$ Hence, to get rid of the dependence to the military force of these Dehqans, Samanid Emirs tried to decrease their authority while inhibiting the power of these competitors. ${ }^{\mathrm{xxxix}}$ This tension of interests between Dehqans and Samanid Emirs made the Emirs to tend to the power of Turk slaves in order to compete the Dehqans and their powerful military force. Hence, by employing and disciplining a large number of Turk Bondmen and Bondwomen, they gradually freed themselves from dependency to the military force of Dehqans. On the other hand, by assigning shares and lands to the other social classes such as jurists, merchants, and slaves, as well as expansion of endowments, ${ }^{\mathrm{xl}}$ they tried to reduce the aristocratic privilege of these Dehqans. Thus, the Dehqan Class lost its importance as an excellent class; and naturally, with tyranny of the Turk slaves and subsequent turmoil, some of them left their lives in Dehqans Class in Transoxiana and migrated to other areas.

\subsection{Embracing Islam by the Turk Nomads}

One of the main problems of Iranian Kingdom over centuries was to maintain the borders of the Northeast from the emigrants' attacks. During the ancient era, these emigrant tribes were generally from Iranian groups; nevertheless, in the late sixth century, the first group of non-Iranian peoples under the name Tukiu-e (or in Islamic references: Turks) with forming a desert empire, could dominate the tribes living in the northern plains from Baikal Lake to near the Black Sea; soon, it was divided into two parts and the plains in the vicinity of Yaxartes were put under the control of Western Turk Khaqan. Hence, the Muslim Arabs became the neighbor of this Turk Khaqan after overcoming Transoxiana. In the early $8^{\text {th }}$ century, Western Turk Khaqan broke down and power emptiness created in the plains around Yaxartes allowed some tribes living near Baikal to migrate to these plains. ${ }^{x l i}$ With the arrival of new tribe groups and the domination of the remnants of Turk tribes, the Tribe Union under the titles of Qalruqs and Oghuz that dominate all eastern and northern plains of Yaxartes, respectively. In this way, from Tarim River to Taraz River, i.e. all Turkistan area of China and Semirchie area were under the control of Qarluqs Union and the plians located in the west of Taraz River to Volga got under domination of Oghuz. ${ }^{\text {xli }}$

In ancient times, conflict between the Iranian of Transoxiana and these migrating tribes was often based on the living and economic differences; but after the Muslim Arabs overcame Transoxiana, the religious differences were added to these living differences and this changed the process of confronting Turk nomads from a defensive to an aggressive process. In this sense, attempts to issue Islam as well as "Nafye Sabil" "xliii Principle (it is an Islamic principle that allows no domination of Non-Muslims over Muslims) encouraged and motivated the Muslims to fight with these tribes. In the shadow of such a great religious motivation, not only the remnants of Turks were driven out of Transoxiana, but also the Muslim Ghazis forced them to issue Islam in deserts of east Yaxartes. This religious differences contributed to consolidate the eastern borders more than anything, because Non-Muslims (except Dhimmi) had no place in Islamic society; thus, these tribes could not enter the Islamic Territories was not possible unless they accept Islam. However both Qarluq and Oghuz Tribe Unions resisted against Islam for more than two centuries and with the support of their military force, finally, from the middle of the fourth century, under the influence of various factors such as commerce, political interactions, the activity of Muslim preachers, and refuging of the Shiites and Sadat Alavi in their territory, they gradually accepted Islam. ${ }^{\text {xliv }}$ Nevertheless, this phenomenon, that is to say the Islamism of Turks affected the demographic texture of the region in three ways:

Until the fourth century, Ghazis were one of the most important strata of the area who were considered as one of the main pillars of Samanid army while fighting with the northern non-Muslim tribes. ${ }^{x l v}$ With the influence of Islam among Turk tribes in the middle of the $10^{\text {th }}$ century, Ghazians become unemployed. This unemployment provided the context for their disruptive behaviors and consequently the social disturbance there. Samanid government directed Ghazis to migrate to the other border areas and other Islamic borders in order to cope with this problem. ${ }^{\text {xlvi }}$ Therefore, by collective migration of Ghazians from Transoxiana, in addition to reduction of the defensive force of the region and weakening the power of Samanids, a part of the demographic composition of the area changed.

\subsubsection{Migration of Turk Tribes to Transoxiana}

As it was said, by the fourth century, in addition to deep living, civil and ethnic differences with the residents of Transoxiana, the desert tribes of northern plains also had religious and ideal differences and this was the most important obstacle for influential passage and presence of these tribes in Transoxiana. Muslim geographers have given many details about the Islamism of Turk tribes around Yaxartes River in the middle of the fourth century. ${ }^{\text {xlvii }}$ With the prevalence of the Islamic teachings among these tribes, an ideal common has been created between them and the residents of Transoxiana that eliminated the obstacles of their passage and presence in the Islamic society. Therefore, Islamism of these tribes was equal to destruction of the eastern gate of Iran (and more precisely, the Islamic Territory).

As Istakhri announces the presence of some converted Turk tribes in the pasturelands around Farab and Konjideh in the 
middle Yaxartes Basin in 950 who did not obey the Muslim Sultans. ${ }^{\text {xlviii }}$ This narrative has been quoted by almost all of the next geographers. ${ }^{\text {xlix }}$ Therefore, obviously the Islamism of Turk tribes had been associated with the permission of their travel to Islamic territory without the need of obeying the Muslim rulers. The tightness of the place and attempts to find a place for the added population and their livestock made the new-Muslim tribes and the force of eastern and northern tribes pushed them to migrate to Transoxiana. These converted tribes who succeeded to form the first Turk Muslim Government under the title of Qarakhanids in Semirchie area started to go to Transoxiana in the continuous attacks of desert-residence to presence (in Transoxiana) and in order to meet their livelihood needs. They first created some problems for the Samanid Emir through supporting his opponents in Farghana. ${ }^{1}$ Then, they continued their advancement by overcoming the silver mines in Ilāq region from the year 975. ${ }^{\text {li }}$ Provocation of the opponents of Samanid Government for the attack of Qarakhanids to Bukhara added the intensity of this problem, ${ }^{\text {lii }}$ finally in 989, after overcoming the Samanid Army under the leadership of Hajib Inanj, Bughqrakhan Harun attached all areas in the east of Yaxartes River to his own territory and then defeated the Samanid Army again under the leadership of Fāeq al-Khașșa in Samarqand and consequently seized the Samanid Thrown in 991. ${ }^{\text {liii }}$ However Bughrakhan returned to his headquarter in Semirchie after appointment of Abdul Aziz Ibn Nuh Ibn Nasr (one of the dissatisfied members of Sasanid Family), ${ }^{\text {liv }}$ but a few years later, in 999, Ilak Khan entered Bukhara pretending to support them and by prisoning the nobles and great rulers and Samanid princes expanded the domination of Qarakhanids to the Oxus Coasts. ${ }^{\text {lv }}$ Therefore, the last Iranian Government was collapsed in the region and Transoxiana was opened for the settlement of tribes under his command. The Samanid Emir who had faced the revenge and rebellions of the slaves that were the mainstay of his power, ${ }^{\text {lvi }}$ united with some converted tribes of Oghuz to compensate his weakness and gave them pasturelands in the south of Qizilqum and the northeast Bukhara, i.e. Nūr Region. ${ }^{\text {lvii }}$

With the arrival of tribes to the sedentary areas, a new style of social life was created in Transoxiana. This means that along with the urban and rural sedentary society that had included almost all population of Transoxiana in the early Islamic centuries, the independent and moving communities were formed. Increase in these tribes in the following decades changed them to one of the important social classes affecting on the society's process and the form of the political system. Invasion, traffic, and migration of the early tribes has been always followed by damaging economic and social results for the civilized areas and certainly the arrival of converted Turks to Transoxiana has not been an exception. However with the effectiveness of the Islamic and Iranian culture and under the direction and advices of the Iranian bureaucrats, these tribes could preserve a valuable and considerable scientific, literary, cultural, and civil heritage, but at the very beginning, they caused much damages to the economic and social life of Transoxiana.

\subsubsection{Migration of the Inhabitants of Transoxiana}

The dominance of Turk slaves in Transoxiana and their domination and consolidation to the Samanid court shattered the social status of Transoxiana. This phenomenon as well as the prevalence of the majestic courts of Khawrazm and Ghazna, and support of the scholars and scientists led to the migration of some of the citizens of Transoxiana such as scientists of that region. ${ }^{\text {lviii }}$ This migration wave intensified with the victory of Qarluq and Oghuz tribes that dominated Transoxiana society after the collapse of Samanids. This intensity was so much that even some of the members of Samanid family intended to go to their city and migrated to neighbor the court of the rulers of Khwarazm and Khorasan. ${ }^{\text {lix }}$ Clearly, by migration of these Iranian groups, the space was provided for further establishment of the ethnic Turk and Mongolian Groups and increase in the settlement of Turks led to the change of the ethnic texture of this region.

\section{Conclusion}

Over many countries, Transoxiana has been always the most eastern and one of the most important states of Iran. Despite the fact that it has been exposed to the continuous invasion of desert tribes, this region has yet had a (basically) Iranian social composition at the begging of Arab conquests. With the victory of Muslim Arabs and during the first Islamic centuries, this demographic composition changed. The Attacks of Nomads has been one of the main factors of change in the pillars of political and civil society of Transoxiana in previous centuries. The location of this state in the eastern borders and its proximity to the Eurasia steppe has a major mission for them to confront Nomads. Presence of and expanded settlement of the Iranian tribes in the separated and independent units of this area led to the emergence of poly-rulers system (the desired system of Aryans). After the emergence of Kingdom (imperial) system in the west of Iran and their centralization of power, regarding the Iranian way of governing the country that one of whose fundamental characteristics was granting internal independence to the border states to consolidate the borders, not only this political system did not change, but also given the major role of Transoxiana in coping with Nomadic attackers, it was stabilized and developed. With this strategy, the path of progress of Eurasia tribes to the Iranian territory was blocked. Although in a few cases, the invader non-Aryan tribes succeeded to overcome this region, the power remained in the hands of the indigenous aristocracies of Iran. The entrance of Muslim Arabs that ended up the life of Sassanid Empire and subsequently the ancient era disturbed the political structure balance and the demographic composition of this region. 
Along with the gradual progress of Arabs to the East and Transoxiana, a large number of aristocrats and elders affiliated to the Caisson court also migrated to this area and took a large part of the Iranian political-cultural heritage with them. Moreover, the necessity of maintaining the captured lands and continuity of conquests made many Arab tribes to migrate and collectively settle in these areas.

In addition to the active commerce of Transoxiana and traffic of different merchants to there, the enthusiasm for participating in the religious operations of Ghaza and preaching Islamic religion also attracted many Muslims from different parts of the Islamic Empire to this area. Consequently, (indeed) a global society was created in Transoxiana. This also contributed to mix the cultural Aryan (eastern Iran), Sassanid (western Iran), and Islamic-Arabic Effects with each other and provided the context for the emergence of Iranian-Islamic culture and civilization. In addition to the expansion of Islam's territory, the expansion of Ghaza operations (especially in the third century) entered many of Nomads under the title of slaves to Transoxiana and Islamic society. retreating Nomads and their gradual familiarity with the Islamic teachings eliminated the necessity of keeping the previous orders in addition to eliminating the cultural barriers of the presence of Nomads in Transoxiana; subsequently, the gates of Transoxiana (and consequently Iran) was opened for the invasion of Nomads in the late fourth century. With ending the life of the last Iranian Dynasty, this led to the basic transformation of the political structure and ethnic-racial change of Transoxiana.

\section{Copyrights}

Copyright for this article is retained by the author(s), with first publication rights granted to the journal.

This is an open-access article distributed under the terms and conditions of the Creative Commons Attribution license (http://creativecommons.org/licenses/by/4.0/).

\footnotetext{
${ }^{\mathrm{i}}$.Bertold Spuler, Iran in Früh-Islamischer Zeit: Politik,Kultur, Verwaltung und öffentliches Leben Zwischen der arabischen und Seldschukischen Eroberung 633 bis 1055 (Wiesbden: Frank Steiner Verlag, 1952), 347-372.

${ }^{i i}$.R.N.Sharp, the Commands of the Achaemenid Kings (Shiraz: The Center Council of Imperial Celebrations, 1967), 33, 76-77, 79, 83; Albert ten Eyck Olmstead, History of Persian Empire (Chicago: University of Chicago press, 1948), 66, 211, 240-241.

iii .Hasan Pirnia, The Ancient Persia (Tehran:Donya-ye Kitab, 1983), 3: 1976, 1993, 2103.

${ }^{\text {iv }}$ René Grousset, The empire of the Steppes, Translated from the French by Naomi Walford (Newjersey: Rutgers university press, 1970), 73; R.N. Frye, the Heritage of Persia (London: Weidenfeld and Nicolson, 1962), 198-207.
}

`.Arthur.I. Christensen, L'Iran Sous Les Sassanides (Copenhague:Levin\& Munksgaard,1936), 109, 254.

${ }^{\text {vi } . M o h a m m a d ~ b . ~ J a r i r ~ T a b a r i, ~ T a r i k h ~ a l-T a b a r i, ~ e d . ~ A b d a ' ~ A l i ~ M u h a n n a ~(B e i r u t: ~ M o ' a s s e s a t ~ a l-' A l a m i ~ L e l-M a t b o u ' a a t, ~}$ 1996),1: 8, 38, 45-47; 'Abd al-Hayy b. Zahhhak Gardrizi, Tarikh-e Gardrizi, ed. Abd al-Hayy Habibi (Tehran: Donya-ye Kitab, 1984), 211; Mohammad b. Ja'afar Narashakhi, History of Bukhara, Tr. AbuNasr Qubavi, Summarized by Mohammad Ibn Zafar Ibn Omar, ed. Mohammad Taqi Modarres Razavi (Tehran: Bunyad-e Farhang-e Iran, 1972 ), 22.

vii . H.A.R. Gibb, the Arab Conquest of Central Asia (New York: AMS press, 1970), 4.

viii. Ahmad b. Yahyya Baladhuri, Fotūḥ al-Buldan (Beirut: Dar wa Maktabat al-Hiilāl,2000), 404-408; Ibn al-A’tham Kufi, al-Fotuh, ed. Ali Shiri (Beirut: Dar al-Aẓwa,1989), 2: 338; Abu al-Rayḥān al-Biruni, Athār al-Baqia 'An al-Qurūn al-Khalia, ed. Edward Sachao (Leipzig, 1923),101-102; Ibn Khurdadbeh, al-Masālik wa al-Mamālik (Leiden: Brill,1889),39-40.

ix. V.V. Barthold, Tutkestan down to the Mongol invasion, Translated from the original Russian by H. A. R. GIBB, (London: Oxford University Press, 1928), 210-215.

x. Baladhuri, 396.

xi . Tabari,4: 515 .

xii. Baladhuri, 397-404; Ya'qubi, al-Tarikh, ed. Khalil Mansur (Beirut: Dar al-Kutub al-'Elmia, 1997), 2: $200-201$.

xiii. Narshakhi, 61, 73 .

xiv . 'Abd al-Karim Sam'ani, al-Ansab, ed. 'Abdallah 'Omar al-Barudi (Beirut: Dar al-Jenan, 1987), 2: 68, 289, 608; 4: 267;

5: 418; Yaqut al-Hamawi, Mo’jam al-Buldan, ed. F. Wüstenfeld (Beirut: Dar Șader, 1977), 5: 369.

xv. Ya'qubi, al-Buldan, ed. Mohammad Amin al-Ẓananāwi (Beirut: Dar al-Kutub al-’Elmia, 1999), 125.

xvi . Tabari, 5: 647-648. 
xvii . Narshakhi, 42-43.

xviii . Suzani Samarqandi, Divan of Poems, ed. Naser al-Din Shah Hosseini (Tehran: Amir Kabir, 1959$), 99$.

xix . Ibn Babwayh, M.I.A.I.H, Ma La Yahzoroho al-Faqih, ed. Seyed Hasan Mousavi Khorsan (Beirut: Dar Șa’ab \& Dar Al-Ta'arrof, 1988), 2-3.

${ }^{x x}$. Abu al-Faraj Isfahani, Maqatil al-Talibiyin, ed. Seyed Ahmad Saqar (Beirut: Mo'asseat al-A'alami le al-Motbu'aāt,1986), 207-210, 263-268.

${ }^{x x i}$. Fakhr Razi, Shajarat al-Mobaraka, ed. Mahdi Al-Rajaei (Qom: Maktabat al-Ayat allah al-'Ozma al-Mar'ashi al-Najafi, 1987), 67.

xxii . Muhammad b. Mhammad Bal'ami, Tarikh-Nameh Tabari, ed. Mohammad Rowshan(Tehran: Soroush,2010), 4: 1152-1153, 1186-1187; Ya'qubi, 1997, 2: 283-286; Mahmud b Muhammad b. Hossein Isfahani, Dastūr al-Vizara, ed. Reza Anzabi Nezhad (Tehran: Amir Kabir, 1985), 550-557; Gardrizi, 176.

xxiii . Ibn Isfandiar, Tarikh-i Tabaristan, ed. Abbas Iqbal (Tehran: Kolaleh Khavar,1987), 1: 194.

xxiv . Muhammad b. Ismail al-Tha'alibi, Yatimat al-Dahr fi Maḥāsen Ahl al-'Așr, ed. Mohammad Moḥye al-Din Abd al-Hamid (Cairo: Matba'at Eisa al-Babi al-Halabi,1954), 4: 192.

xxv . Hudud al-’Aālam, ed. Manuchehr Sotoudeh (Tehran: Tahuri,1983), 105-107.

xxvi Ata Malek Juvaini, Tarikh-e Jahangushay, ed. Muhammad Qazvini (Tehran: Donya-ye Ketab,1996),1: 81.

xxvii . Ahmad b. Muhammad al-Maqdisi, Ahsan al-Taqāsim fi Ma'rifat al-Aqālim, ed. Mohammad Makhzum (Beirut: Dar al-Ihya al-Turath al-Arabi, 1986), 220.

xxviii . Ibn Hawqal, Șūrat al-Arẓ (Leiden: Brill, 1967), 465.

${ }^{x x i x}$.Ibn Hawqal, 466-467; Zakaria.b.Muhammad Qazvini, Athar al-Bilād wa Akhbar al-'Ibād (Beirut: DarSader,1959), 558.

xxx . Ibrahim b. Muhammad al-Istakhri, Masālik wa al-Mamālik (Old Persian Translation), ed. Iraj Afshar (Tehran: 'Elmi va Farhangi, 1989), 229; Yaqut al-Hamawi, Mo’jam al-Buldan, 5: 46-47.

xxxi. al-Maqdisi, 252-253.

xxxii . Mo'ein al-Fuqara, Ahmad b. Muhammad, Tarikh-e Mulazadeh Dar Dhikr-e Mazarat-e Bukhara, ed. Ahmad Golchin Ma'ani (Tehran: Ibn Sina, 1960),18-19, 39, Ibn Khallikan, Wafayyāt al-A'ayān, ed.Ihsan Abbas (Beirut: Dar Șādir,1987), 3: 226.

xxxiii . Sam'aāni, 1: 99; 4: 245, 456, 361; 5: 140, 563, 564.

${ }^{\text {xxiv }}$.Yashtaha, in Zoroastrian Literature, ed. Mohammad Ibrahim Pour Davoud (Bombay: Unnamed, no date), 1: 435, 461; Frye, the Heritage of Persia, 50-52.

${ }^{\mathrm{xxxv}}$. Arnold Toynbee, A Study of History, vol.7 (London: Oxford University press, 1954), 588-589, 674.

xxxvi . Toynbee, 588 .

xxxvii . Narshakhi,16; R.N.Frye, Bukhara: The Medieval Achievement (Oklahama: University of Oklahama,1965), 77, 179, 218; Barthold, 159.

xxxviii . Ibn Isfandiar, 1: 271; Hamdallah Mostowfi, Tarikhe Guzideh, ed. Abd al-Hossein Navaei (Tehran: Amir Kabir, 1985), 379; Minhaj-e Siraj Jowzjani, Tabaqat-e-Naseri, ed. Abd al-Hay Habibi (Tehran: Donya-ye ketab, 1984), 1: 208; Mirkh $_{\mathrm{w}}$ and, Muhammad b. Khavand, Rowzat-al-Safa (Tehran: Piruz-Khayam,1960), 4: 41.

xxxix . Frye, Bukhara, 77, 179; Barthold, 159.

xl . Narshakhi,43,46.

xli . Pritsak, Omeljan, "The Decline of the Empire of the Oghuz Yabghu”, In Studies In Medieval Eurasian History ( ${ }^{\text {London: }}$ variorum reprints, 1981), 288-289.

xlii . Qazvini, 558;, Abu al-Qasim b. Ahmad Jeyhani, Ashkal al-‘Alam, Translated by Ali B. Abd al-Salam, ed. Firuz Mansuri( Mashhad: Beh Nashr, 1989), 177.

xliii . Quran, Sura , Nisa:141.

xliv . Rahmati, Mohsen, "The Spread of Islam in the Realm of Qarluq People”, Historical sciences Resaerches (vol. 5, No. 1, Spring and Summer 2013), 58-69. 
xlv . Narshakhi, 114; Tarikh-e Sistan, ed. Mohammad Taqi Bahar (Tehran: Kolaleh Khavar, 1939), 256.

xlvi . Ibn Miskawayh, Tajarib al-Omam, ed. H.F. Amidruz (Baqdad: Maktabat al-Muthanna, 1914),3: 201-203, 222-228; Ibn al-Athir, al-Kamel Fi al-Tarikh, ed. K. J.Tornberg (Beirut: Dar-e-Sader, 1978), 8: 569-571.

xlvii . Istakhri,265; Hudud al-Alam, 117; Sharif al-Idrisi, Nuzhat al-Mushtaq fi Ikhtiraq al-Afaq (Cairo: Maktabat al-Thiqafat al-Dinia, no date), 2: 706.

xlviii . Istakhri, 264.

xlix . Hudud al-Alam, 118; Ibn Hawqal, 511; Jeyhani, 193; Sharif al-Idrisi, 2: 705.

1. Jowzjani, 1: 211.

li . Frye, Bukhara, 199.

lii . Nāṣiḥ b. Zafar Jurfadiqāni, Tarjeme-ye Tarikh-e Yamini, ed. Ja'far Shoa'ār (Tehran: Bongāh-e Tajeme va Nashr-e Kitab,1975), 92.

liii . Mostowfi, 385; Rashid al-Din Fazlullah Hamadani, Jāmi` al-Tawārīkh, ed. Mohammad Dabir Siaqi (Tehran: Forouqi, 1959),34.

liv . Abu al-Faẓl Baihaqi, Tarikh-e Baihaqi, ed. Ali Akbar Fayyaz (Tehran: Nashr-e 'Elm, 1995), 251.

lv . Qaẓi Ahmad Ghaffari, Tarikh-e Jahanārā, ed.Hasan Naraqi (Tehran: Ḥafiż, 1963), 163; Heydar b. Ali Razi, Majma al-Tawarikh, In notes on Tarikh-e Beyhaqi by Saeid Nafisi (Tehran: Ibn Sina, 1953), 1163;'Abd al-Raḥman b. Ali Ibn al-Jowzi, al-Muntażam fi al-Tarikh Muluk wa al-Omam (Heydar Abad al-Dakan: Matba'at Dāyerat al-Ma'arif al-'Othmānia, 1936-1939), 7: 202.

lvi . Muhammad b. Ismail al-Tha'alibi, Khāșṣ al-Khāșș, ed. Hasan al-Amin (Beirut: Dar wa Maktabat al-Hayat, 1966), 15; Gardrizi, 369.

lvii . Sadr al-Din Hosseini, Akhbar al-Dawlat al-Saljuqia, ed. Mohammad Shafi' (Lahore: Punjab university press, 1933), 2; Ibn al-Athir, 9: 475, Mirkh ${ }_{w}$ and, 4: 238.

lviii . Yaqut al-Hamawi, Mo'jam al-Udaba, ed. Ehsan Abbas (Beirut: Dar al-Qarb al-Islami, 1993), 2: 857; Ibn Khallikan, 5: 122, 457-458.

lix . Yaqut al-Hamawi, Op.cit., 4:1494;Shams al-Din Dhahabi, Seyar A'lam al-Nobala, ed. Shoayb Arnovut et al. (Beirut: Mo'assesat al-Resalat, 1982), 17: 493; Mahmud b Muhammad b. Hossein Isfahani, 101; Juvaini, 2: 29. 